\title{
Credit risk stress testing in a cluster of Russian commercial banks
}

\author{
Davit S. Bidzhoyan
}

E-mail: bidzhoyan_david@mail.ru

\section{Tatiana K. Bogdanova}

E-mail: tanbog@hse.ru

\author{
Dmitry Yu. Neklyudov \\ E-mail: nekludovmid@gmail.com
}

National Research University Higher School of Economics

Address: 20, Myasnitskaya Street, Moscow 101000, Russia

\begin{abstract}
Stress testing as an instrument of risk evaluation is actively used in many international organizations, as well as by central banks in many countries. Some organizations (including the Bank of Russia) when conducting stress testing do not publish results of the tests, though they are interesting for the business community. They are reticent so to avoid causing panic on markets which could lead to a massive outflow of deposits from the banking sector as a whole or from some individual banks in particular. As a rule, stress testing is conducted relying on huge number of unpublished reporting forms, but the business community has no access to them. Only four reporting forms are presented on the Bank of Russia's website. In this paper we propose a simplified algorithm of credit risk stress testing of a banking cluster based on the four officially published reporting forms. The algorithm provides modelling of median values of banking variables depending on macroeconomic indicators, and subsequent retranslation of the received values for assessing the financial position of each bank included in the cluster. It is assumed that growth rates of banking indicators obtained from the econometrics models relying on median values are the same for each bank in the cluster. As of 1 January 2018, credit risk stress testing was conducted for 26 banks, nine of which are system-significant credit institutions. Within the stress testing, eight econometric time series models were developed. As a result, it was discovered that 11 out of 26 banks in the cluster will face certain difficulties regarding statutory requirements related to capital ratios or buffers.
\end{abstract}




\section{Graphical abstract}

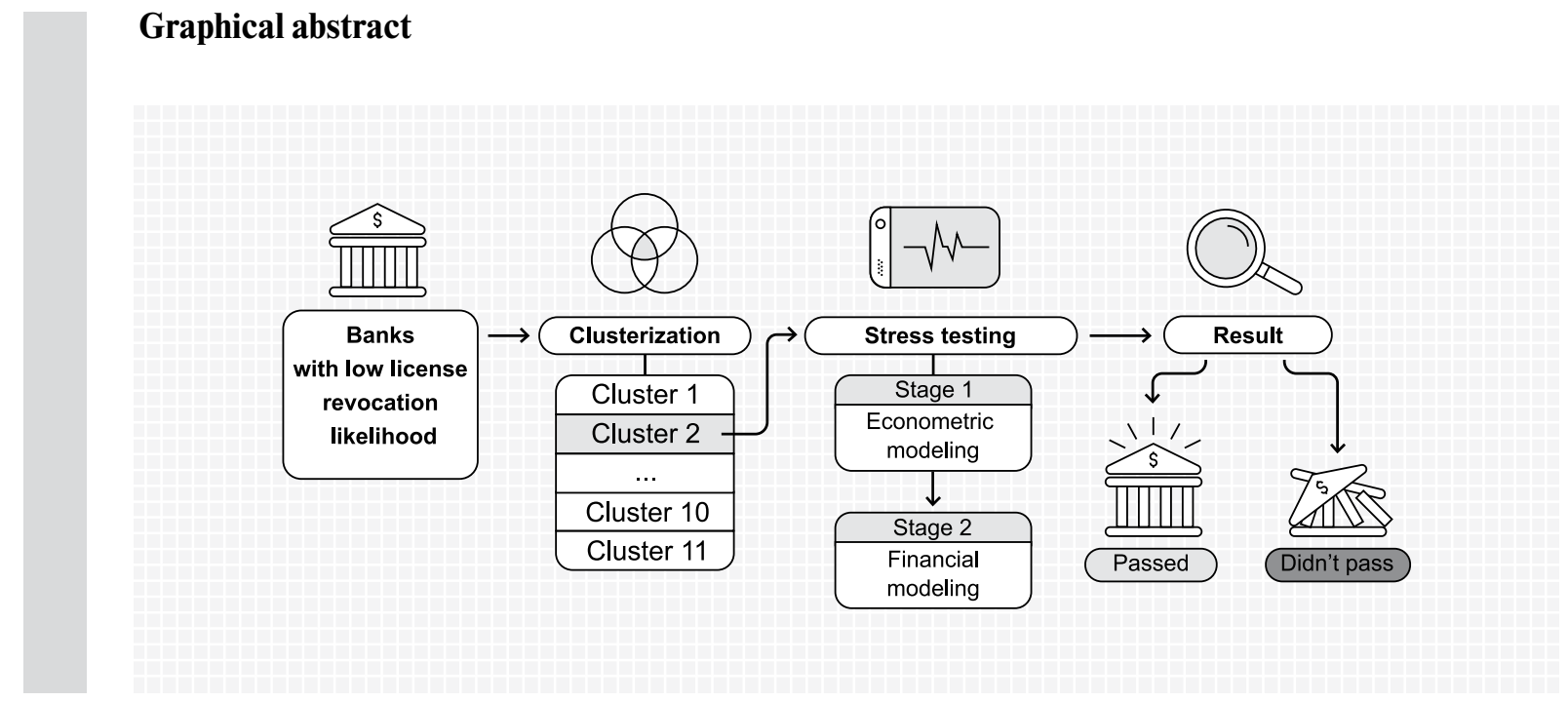

Key words: stress testing; credit risk; macroeconomic indicator; econometric model; system-significant credit institutions; median.

Citation: Bidzhoyan D.S., Bogdanova T.K., Neklyudov D.Yu. (2019) Credit risk stress testing in a cluster of Russian commercial banks. Business Informatics, vol. 13, no 3, pp. 35-51.

DOI: $10.17323 / 1998-0663.2019 .3 .35 .51$

\section{Introduction}

$\mathrm{T}$ The financial statement of banks largely depends on the macroeconomic environment in which banks have to operate. This dependence is manifested both directly and indirectly. Direct impact is through the revaluation of assets and liabilities depending on the base parameter. For example, the open foreign-currency position of banks directly depends on the value of the exchange rate to the Russian ruble; the fair value of the bonds depends on the yield curve to maturity, which rises during crisis periods; and the value of shares falls as the market index falls. The indirect effect is through the financial statements of the bank's borrowers, which lead to a change in the assets quality. As a rule, during crisis periods the financial statements of borrowers deteriorate, setting the need to charge additional loan loss provisions (LLP), all of which leads to a decrease in the bank's capital.
Since banks play the central role in a market economy, being the "circulatory system" of the economy, all market participants are interested in assessing a bank's financial statement, including the Central Bank of the Russian Federation. It has all possible information on the activities of banks, due to the large number of reporting forms provided on a regular basis. In addition to the Bank of Russia, the financial statement of banks is interesting to their creditors, depositors and investors, and mostly to legal entities whose deposits and funds on settlement accounts are not insured by the state, unlike deposits of individuals. Moreover, creditors of Russian commercial banks are deprived of the possibility of deep analysis of the bank's financial statements due to limited information: there are only four reporting forms on the Bank of Russia website that allow one to assess the financial statements of banks.

Due to the current geopolitical situation and the continuing policy of the Bank of Russia to 
improve the banking sector, many banks are at risk of default. A rough estimate of the impact of a deteriorating macroeconomic environment on the financial condition of banks can be obtained using stress testing methods. The results of stress testing conducted by the Bank of Russia are not published, but nevertheless, they may be of interest to the bank's lenders and depositors. The paper [1] presents the stress testing algorithm for a bank's credit risk on an individual basis based on official, publicly available financial reports. However, conducting stress testing of the credit risk of a large number of banks is laborious. Therefore, it is important to develop a credit risk stress testing algorithm for a cluster of banks.

This paper has the following structure. The first paragraph provides a brief overview of papers by Russian and foreign scientists on the subject of the study; the second section presents the stress testing algorithm for a cluster of banks; and the third presents the stress testing results of certain bank clusters. In the conclusion, the main results of the study are formulated.

\section{Methods and models for assessing the banks' financial position}

A large number of scientific papers by both foreign and Russian authors are devoted to the analysis of a bank's financial statements. All mathematical models can be divided into several categories:

$\checkmark$ estimating probability of default [2-6];

$\downarrow$ evaluating the financial statements by ratings $[7,8]$;

$\downarrow$ models of technical efficiency [9, 10];

$\downarrow$ interest rate models [11-13].

The afore-mentioned methods model the current financial statement of a bank, while stress testing methods allow us to simulate the effect of various macroeconomic shocks on the banks' financial position.

Stress testing as a tool for bank risk assessment appeared in the 1990s. However, it became pop- ular only after the financial crisis of 2007-2009. Today the central banks of almost all countries with developed and developing economies use stress testing to assess future risks during crisis periods. In addition, stress testing as a risk assessment tool is used by international organizations such as the Basel Committee on Banking Supervision and the International Monetary Fund. A classification of stress testing tools is given in [14].

Credit risk, as the main source of losses, can be measured in various ways. Organizations that possess the necessary data use non-performing loans (NPL) [15], loans of quality categories 4-5 (according to the Bank of Russia Regulation No 590-P dated 28 June 2017 "On the Procedure for Making Loss Provisions by Credit Institutions for Loans and Similar Debts"), as well as their share in the portfolio. However, paper [1] presents an algorithm for credit risk stress testing based on publicly available financial reports; it proposes to use the volume of LLP, which can be calculated relying on changings accounts balances, as a measure of credit risk. In this paper, we also use LLP to measure credit risk.

Stress testing based on scenario analysis should be conducted by regressing the volume of NPL on macroeconomic variables. As a rule, simple regression models are used, as shown in [16]. A more complex model based on panel data is presented in [15].

One of the key points in stress testing is the stress scenario development. One of the main criteria should be its severity and plausibility. Central banks use one or more stressful scenarios. This can lead to false positive results (the "false illusion" effect), since in one stressful scenario the bank may come to a state of default, and in another - will not. Calculating for all scenarios leads to computational burden. Therefore, in [17] the principle of "the most severe plausible scenario" was proposed. Plausibility can be calculated based on the Mahalanobis distance [18], the Kulbek-Leibler distance, the Bregman distance, and the $f$-divergence method [19]. 
The large number of macroeconomic factors that directly or indirectly affect the financial statements of banks should be taken into account when conducting stress testing. For example, the Bank of England when stress testing the seven largest banks uses 58 macroeconomic indicators $^{1}$ and work with them is extremely difficult. Many studies have proposed methods for reducing the dimensionality: in particular, the principal component method [20] and other methods that reduce the dimensionality [21] are used.

The bank can sell a part of its assets with a high risk ratio at a large discount in order to meet the capital adequacy ratios and premiums. The mathematical formalization of such behavioral models is described in detail in [22-24].

\section{An algorithm of stress testing for a cluster of banks}

In [25], an information-logical model for identifying a group of reliable banks is presented. This model has four stages:

Stage 1. Collection and aggregation of official public reporting data and the macroeconomic variables;

Stage 2. Building the logistic regression model for estimating the probability of license revocation of Russian commercial banks and determining the optimal cut-off value;

Stage 3. Grouping banks with a low probability of license revocation based on cluster analysis or on the basis of specified criteria;

Stage 4. Stress testing the credit risk of a selected group of banks in order to identify whether the capital is sufficient to cover losses associated with credit risk as the main source of losses. Banks whose capital adequacy ratios are above the minimum values at the end of a stressful period are considered to be reliable.

This paper proposes an algorithm for conducting credit risk stress testing for a group of banks which is an extension of the algorithm presented in [1]. The simulation includes eight banking indicators, depending on macroeconomic variables:

$\checkmark$ corporate LLP;

$\checkmark$ retail LLP;

$\downarrow$ corporate loans;

$\checkmark$ retail loans;

$\checkmark$ individual deposits;

$\checkmark$ corporate deposits;

$\downarrow$ funds on individuals current accounts;

$\downarrow$ funds on corporate settlement accounts.

The following macroeconomic variables are used as risk factors in the credit risk stress testing framework:

$\checkmark$ mean, standard deviation and variance of the exchange rate of the US dollar, in rubles;

$\checkmark$ mean, standard deviation and variance of the cost of a barrel of Brent oil, in US dollars;

$\downarrow$ mean, standard deviation and variance of the interbank lending rate $\mathrm{MIACR}^{2}$, in \%;

$\checkmark$ mean, standard deviation and variance of the MICEX ${ }^{3}$ index, in points;

$\checkmark$ mean value, standard deviation and variance of the RTS index, in points;

$\checkmark$ real GDP growth rate (compared to the same quarter of previous year), in \%;

४ the consumer price index growth rate (compared to the same quarter of previous year), in \%;

$\checkmark$ the population real income growth rate (compared to the same quarter of previous year), in \%;

$\checkmark$ the growth rate of expenditures of the population (compared to the same quarter of previous year), in \%;

$\downarrow$ the growth rate of imports (compared to the same quarter of previous year), in $\%$.

The whole process of stress testing is divided into two main blocks: econometric modeling and financial modeling.

${ }^{1}$ https://www.bankofengland.co.uk/stress-testing

${ }^{2}$ MIACR - Moscow Inter-Bank Actual Credit Rate

${ }^{3}$ MICEX - Moscow Interbank Currency Exchange 
Within the first block, econometric modeling of bank indicators is carried out. At each time point (selected modeling step) for the analyzed cluster of banks, for each of the eight bank indicators, their median values are calculated. They are further used in calculating the growth rate of banking indicators depending on macroeconomic variables based on econometric models, which are estimated using the least squares method (OLS). In the case of the presence of autocorrelation and / or heteroscedasticity of residuals, the heteroskedasticity and autocorrelation consistent (HAC) Newey-West robust standard errors are used.

Parameters of the simulation procedure for credit risk stress testing are shown in Table 1.

\section{Parameters of credit risk stress testing simulation}

Table 1.

\begin{tabular}{c|c}
\hline Interval & quarter \\
\hline Simulation period & Q1 2008 - Q4 2018 \\
\hline Forecasting horizon & 1 year (4 quarters) \\
\hline Stress scenario & 2015 year $^{4}$ \\
\hline
\end{tabular}

Table 2 shows the necessary data for conducting a credit risk stress test.

In the second block (financial modeling), based on the predicted values of banking indicators in the stress period obtained at the first stage, the adequacies of total, Tier 1 and Common equity Tier 1 capitals are calculated for each bank in order to assess whether the bank will be able to meet the capital adequacy requirements in stress.

Within this framework, the capital adequacy ratios are calculated in three steps.

Step 1. Calculation of capital adequacy ratios after additional charges of LLP on existing loan portfolios according to the formula:
Data for credit risk stress testing

\begin{tabular}{c|c|c} 
Variable & $\begin{array}{c}\text { Reporting } \\
\text { form }\end{array}$ & $\begin{array}{c}\text { Aggregation } \\
\text { code }\end{array}$ \\
\hline $\mathrm{N}_{1.0}$ & $0409135^{5}$ & $\mathrm{H} 1.0$ \\
\hline $\mathrm{N}_{1.1}$ & 0409135 & $\mathrm{H} 1.1$ \\
\hline $\mathrm{N}_{1.2}$ & 0409135 & $\mathrm{H} 1.2$ \\
\hline High liquid assets & 0409135 & LAM \\
\hline Liquid assets & 0409135 & LAT \\
\hline Total capital & $0409123^{6}$ & 000 \\
\hline Tier 1 capital & 0409123 & 106 \\
\hline $\begin{array}{c}\text { Common equity } \\
\text { Tier 1 capital }\end{array}$ & 0409123 & 102 \\
\hline
\end{tabular}

$$
H_{1 ., i, t}^{k}=\frac{K_{i, t}^{k}-\sum_{j=1}^{2} \Delta \hat{R}_{j, t}^{k}}{R W A_{i}^{k}-\sum_{j=1}^{2} c r_{j} \cdot \Delta R_{j, t}^{k}},
$$

where $k$-bank in the cluster;

$H_{1 ., i, t}^{k}$ - the value of $i$-th capital adequacy ratio of bank $k$ at time $t^{7}$;

$K_{i, t}^{k}-i$-th capital of bank $k$ at time $t$;

$\Delta \hat{R}_{j, t}^{k}$ - the forecasted charge of $L L P$ in existing portfolio $j$ of bank $k(j=1-$ corporate loans portfolio; $j=2-$ retail loans portfolio);

$c r_{j}-$ risk coefficient of portfolio $j$;

$R W A_{i}^{k}-$ risk weighted assets of capital $i$ of bank $k$.

Step 2. Calculate the growth of loan portfolios in three stages, as shown in Figure 1.

The following designations in the formulas in the figure are used:

$Z_{j, t}^{k}$ - the actual value of $j$-th portfolio of bank $k$ at time $t+1(j=1-$ corporate loans portfolio; $j=2-$ retail loans portfolio);

\footnotetext{
${ }^{4}$ The historical scenario of 2015 means using the values of the parameters that were in 2015 as the basis of the stress scenario in 2018

${ }^{5}$ Reporting Form 0409135 "Information on Credit Institutions' Required Ratios and Other Performance Indicators"

${ }^{6}$ Reporting Form 0409123 "Capital Calculation (Basel III)"

${ }^{7}$ Hereafter under "at time $t$ " we consider the end of quarter
} 


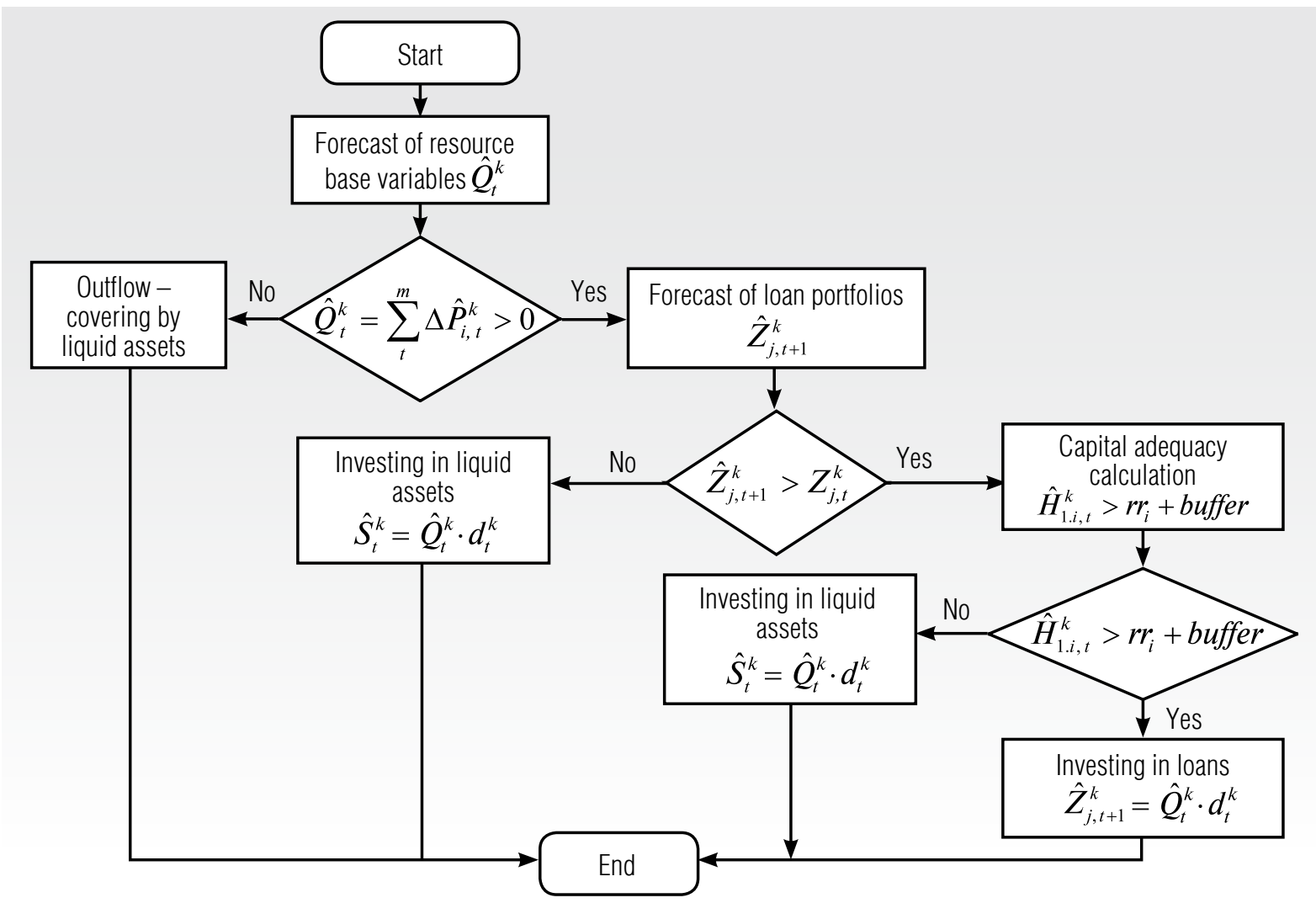

Fig. 1. The scheme for calculating the volume of portfolio increase

$\hat{Z}_{j, t+1}^{k}-$ the forecasted value of $j$-th portfolio of bank $k$ at time $t+1(j=1-$ corporate loans portfolio; $j=2$ - retail loans portfolio);

$\hat{Q}_{t+1}^{k}-$ the surplus of resource base of bank $k$ at time $t$;

$\hat{S}_{t}^{k}-$ the growth of resource base of bank $k$ at time $t$;

$d_{t}^{k}-$ the share of $j$-th portfolio in total assets of bank $k$;

$\hat{P}_{i, t}^{k}$ - the $i$-th resource base of bank $k$ at time $t$;

$H_{1 . i}^{k}-$ the estimated $i$-th capital adequacy ratio;

$r r_{i}-$ the $i$-th capital minimum required ratio; buffer - buffer to capital adequacy ratios.

At the first stage, one checks whether there is an inflow of the resource base. If there is an outflow of the resource base, the deficit is covered by liquid assets. If there is an inflow, then transition to stage 2, within the framework of which the demand for loans from banks is checked. If demand falls, then the surplus inflow is invested in liquid assets, otherwise transition to stage 3. The availability of the necessary capital to meet the capital requirements is checked. If all requirements are met, the funds are invested in the loan portfolio, otherwise - in liquid assets.

Step 3. Calculation the capital adequacy ratios taking into account the additional charge of LLP of newly issued loans using the formula:

$$
\begin{aligned}
& \hat{H}_{1 . i, t \text { new }}^{k}= \\
& =\frac{\hat{K}_{i, t \text { new }}^{k}-c p \cdot \sum_{j=1}^{2} \Delta \hat{Z}_{j, t}^{k}}{\widehat{R W A_{i, t \text { new }}^{k}}+\sum_{j=1}^{2} c r_{j} \cdot\left(\Delta \hat{Z}_{j, t}^{k}-c p \cdot \Delta \hat{Z}_{j, t}^{k}\right)},
\end{aligned}
$$

where $k$ - bank in the cluster;

$\hat{H}_{1 . i, t \_ \text {new }}^{k}-$ the estimated value of $i$-th capital adequacy ratio of bank $k$ at time $t$ taking into account newly issued loans; 
$\hat{K}_{i, t \text { new }}^{k}-$ the estimated $i$-th capital of bank $k$ at time $t$ taking into account taking into account charged LLP of newly issued loans;

$\Delta \hat{Z}_{j, t}^{k}-$ the forecasted value of $j$-th portfolio growth of bank $k$ at time $t(j=1$ - corporate loans portfolio; $j=2$ - retail loans portfolio);

$c r_{j}$ - risk coefficient of portfolio $j$;

$c p$ - LLP on newly issued loans;

$\widehat{R W A}_{i, t \text { new }}^{k}$ - the estimated risk weighted assets of capital $i$ of bank $k$ taking into account charged LLP of newly issued loans.

For those banks that do not meet capital requirements, the additional capitalization volumes are calculated by the formula:

$$
\hat{D}^{k}=\max \left\{\left(\text { required } H_{1 . i}-\hat{H}_{1 . i}^{k}\right) \cdot \widehat{R W A}_{i}^{k}\right\},
$$

where $\hat{D}^{k}-$ the estimated deficit of capital of bank $k$;

required $H_{1 i}-$ minimum required capital adequacy ratio $(i=0-$ total capital, $i=1-$ Common Equity Tier 1 Capital, $i=2-$ Tier 1 Capital);

$\hat{H}_{1 i}^{k}$ - the final estimated value of $i$-th capital adequacy ratios of bank $k$;

$\widehat{R W A}_{i}^{k}$ - the final estimated risk weighted assets of $i$-th capital of bank $k$.

Banks that comply with capital adequacy requirements on them are considered reliable for investments.

\section{Stress testing the largest Russian bank cluster}

In [14], a cluster analysis was conducted on banks (334 banks) with a low probability of license revocation as estimated on the basis of a logistic regression model. According to cluster analysis results, 11 clusters were obtained. Table 3 shows the distribution of banks by clusters.

In this paper, we carried out stress testing of the credit risk of the second cluster of banks, which includes the largest Russian banks. The list of banks forming the second cluster is given below in Table 13.

Table 3.

Distribution

of banks by clusters

\begin{tabular}{c|c} 
No of cluster & Number of banks \\
\hline 1 & 63 \\
\hline 2 & 26 \\
\hline 3 & 15 \\
\hline 4 & 10 \\
\hline 5 & 63 \\
\hline 6 & 28 \\
\hline 7 & 45 \\
\hline 8 & 23 \\
\hline 9 & 29 \\
\hline 10 & 14 \\
\hline 11 & 9 \\
\hline
\end{tabular}

\subsection{Econometric models} for predicting banking variables

\section{Modeling the volume of individuals' deposits}

The banks' deposits from individuals in the second cluster positively depend on the real GDP growth rate, with a lag of one quarter. The results of the econometric model are presented in Table 4.

The following designations are used in the table:

$y_{t}-$ individuals' deposits;

$x_{1, t-1}-$ real GDP growth at time $t-1$ (in $\%$, compared to the same quarter of the previous year).

The model is fully appropriate, since tests for autocorrelation and heteroscedasticity indicate their absence, and the high value of the adjusted $\mathrm{R}^{2}$ and a low value MAPE mean the model is good for prediction. The graph of forecast values of the volume of individual deposits of banks of the second cluster in the stress scenario is shown in Figure 2. 


\section{Results of modeling individuals' deposits}

Table 4.

\begin{tabular}{c|c|c|c|c} 
Variable & Coefficient & Test & Statistics & $p$-value \\
constant & 1.34 & Darbin-Watson & 1.66 & \\
\hline $\operatorname{pcy}\left(y_{t-1}\right)$ & $0.86^{\star \star *}$ & Breusch-Godfrey & 0.53 & 0.59 \\
\hline$x_{1, t-1}$ & $0.37^{\star}$ & Breusch-Pagan-Godfrey & 1.39 & 0.26 \\
\hline $\mathrm{R}^{2}$ adj & 0.68 & White test & 2.07 & 0.09 \\
\hline $\mathrm{MAPE}$ & $4.33 \%$ & \multicolumn{2}{|}{} \\
\hline
\end{tabular}

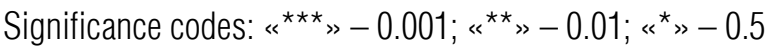

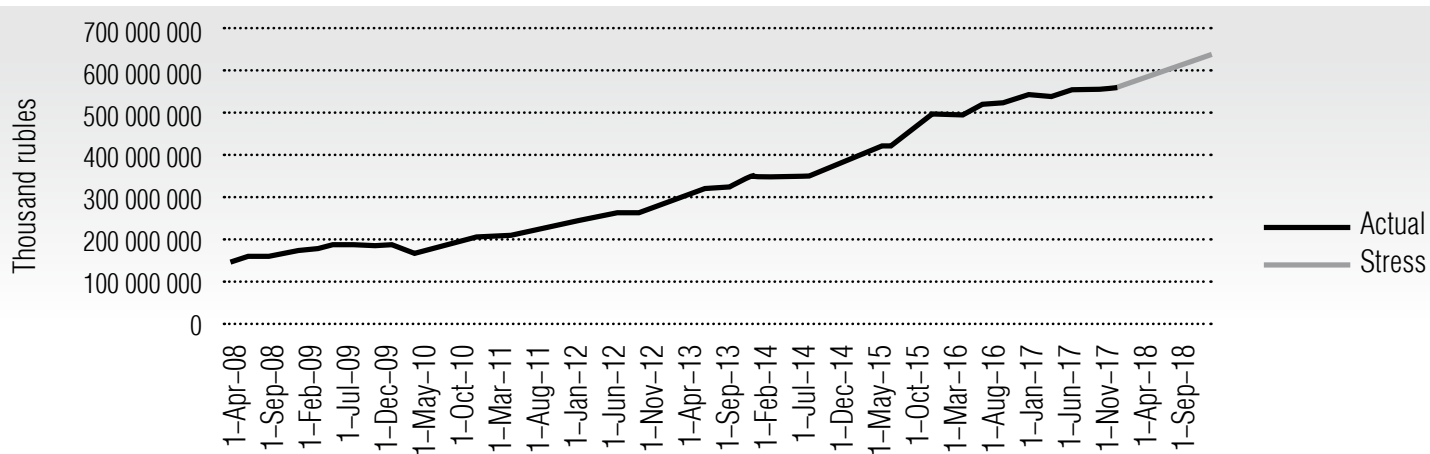

Fig. 2. The actual and forecasted values of individuals' deposits

\section{Modeling the volume of corporate deposits}

The volume of corporate deposits positively depends on the real growth rate of GDP with a lag of two quarters. The model also has an autocorrelation component. The simulation results are presented in Table 5.

The following designations are used in the table: $y_{t}$ - corporate deposits;

$x_{1, t-2}-$ real GDP growth at time $t-2$ (in $\%$, compared to the same quarter of the previous year).

The model has autocorrelation, to eliminate the negative effects of which the Newey-West robust standard errors were applied. However, the model residuals are homoscedastic.

\section{Results of modeling corporate deposits}

Table 5.

\begin{tabular}{c|c|c|c|c} 
Variable & Coefficient & Test & Statistics & $p$-value \\
constant & 5.01 & Darbin-Watson & 2.24 & \\
\hline $\operatorname{pcy}\left(y_{t-1}\right)$ & $0.64^{\star * *}$ & Breusch-Godfrey & 4.00 & 0.027 \\
\hline$x_{1, t-2}$ & $1.33^{*}$ & Breusch-Pagan-Godfrey & 0.92 & 0.40 \\
\hline $\mathrm{R}^{2}$ adj & 0.62 & White test & 1.35 & 0.26 \\
\hline $\mathrm{MAPE}$ & $4.53 \%$ & \multicolumn{2}{|}{} \\
\hline
\end{tabular}

Significance codes: « ${ }^{\star \star \star} »-0.001 ; «^{\star \star} »-0.01 ; «^{\star} »-0.5$ 
The actual and forecasted values of corporate deposits of banks of the second cluster in the stress scenario are shown in Figure 3.

\section{Modeling the volume of the retail loans portfolio}

The real GDP growth rate with a one quarter lag has a positive effect on the volume of the retail portfolio of banks in the second cluster, while the unemployment rate is negative. The simulation results are presented in Table 6.

The following designations are used in the table:

$y_{t}-$ retail loans portfolio;

$x_{1, t-1}$ - real GDP growth at time $t-1$ (in $\%$, compared to the same quarter of the previous year);

$x_{2, t}$ - the unemployment rate at time $t$ (in \%).

The model residuals are autocorrelated, but homoscedastic. To eliminate the negative effects of autocorrelation, the Newey-West robust standard errors were applied. The high value of adjusted $\mathrm{R}^{2}$ and the low MAPE indicate the suitability of the model for prediction. The actual and forecasted values of the retail loans portfolio of banks of the second cluster in the stress period are shown in Figure 4.

\section{Modeling the volume of the corporate loans portfolio}

Interest rates of corporate loans over a year (negatively) and prices for a barrel of Brent crude oil (positively) determine the volume of the corporate portfolio of banks in the second cluster. The simulation results are presented in Table 7.

The following designations are used in the table:

$y_{t}$ - the volume of corporate loans portfolio;

$x_{1, t}-$ corporate loan's interest rate at time $t$ (in \%);

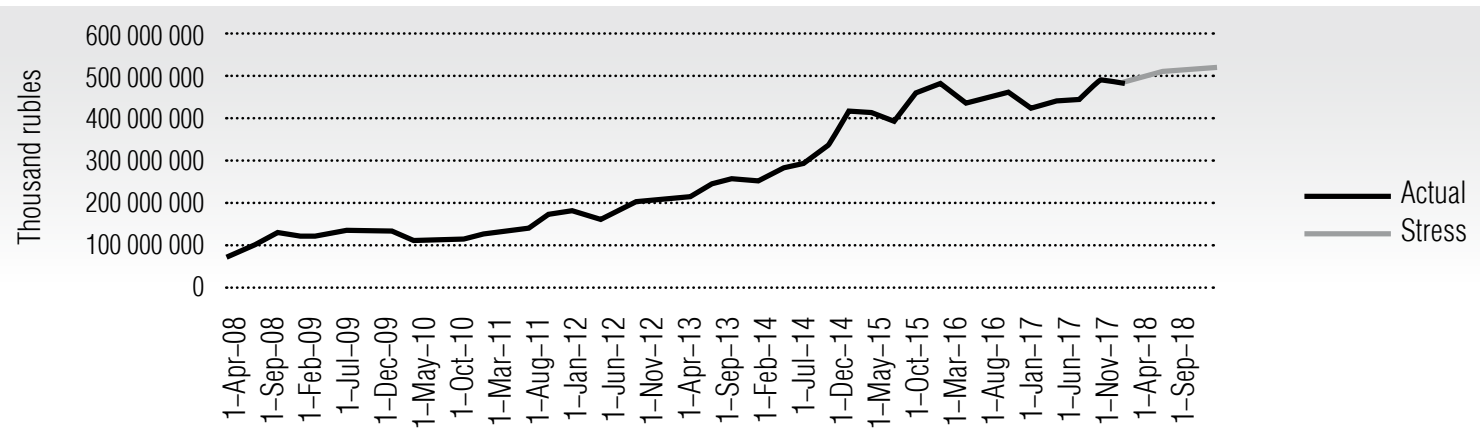

Fig. 3. The actual and forecasted values of corporate deposits

Table 6.

Results of modeling the retail loans portfolio

\begin{tabular}{c|c|c|c|c} 
Variable & Coefficient & Test & Statistics & p-value \\
constant & $-0.72^{\star \star \star}$ & Darbin-Watson & 1.11 & \\
\hline $\mathrm{pcy}\left(y_{t-1}\right)$ & $0.73^{\star \star \star}$ & Breusch-Godfrey & 3.98 & 0.028 \\
\hline$x_{1, t-1}$ & $1.57^{\star \star \star}$ & Breusch-Pagan-Godfrey & 2.28 & 0.096 \\
\hline$x_{2, t}$ & $-0.34^{\star \star \star}$ & White test & 1.44 & 0.21 \\
\hline $\mathrm{R}^{2} \mathrm{adj}$ & 0.86 & \multicolumn{2}{|}{} \\
\hline $\mathrm{MAPE}$ & $6.71 \%$ & \multicolumn{2}{|}{} \\
\hline
\end{tabular}

Significance codes: $\left\langle^{\star \star \star} »-0.001 ; «^{\star \star} »-0.01 ; «^{\star} »-0.5\right.$ 
$x_{2, t-1}-$ the mean price of Brent oil at time $t-1$ (in US dollars).

The model is adequate and suitable for prediction. The model residuals are not autocorrelated and homoscedastic, adjusted $\mathrm{R}^{2}$ high, MAPE. The actual and forecasted values of the corporate loans portfolio of banks in the second cluster in the stress scenario are shown in Figure 5.

\section{Modeling the volume of retail LLP}

The retail LLP are negatively dependent on the real GDP growth rate. Also in the model there is an autocorrelation component. The simulation results are presented in Table 8 .

The following designations are used in the table:

$y_{t}-$ retail LLP;

$x_{1, t}-$ real GDP growth rate at time $t$ (in \%, compared to the same quarter of previous year).

The results of the Breush-Godfrey, BreushPagan-Godfrey, and White tests indicate that there is no autocorrelation and heteroscedasticity in the model residuals. The model is adequate and suitable for prediction. Figure 6 shows a graph of actual and forecasted values of retail banks LLP in a stress scenario.

\section{Modeling the volume of corporate LLP}

The value of corporate LLP of banks of the second cluster is negatively dependent on the real GDP growth rate and the price of Brent crude oil. The results of the model are presented in Table 9.

The following designations are used in the table:

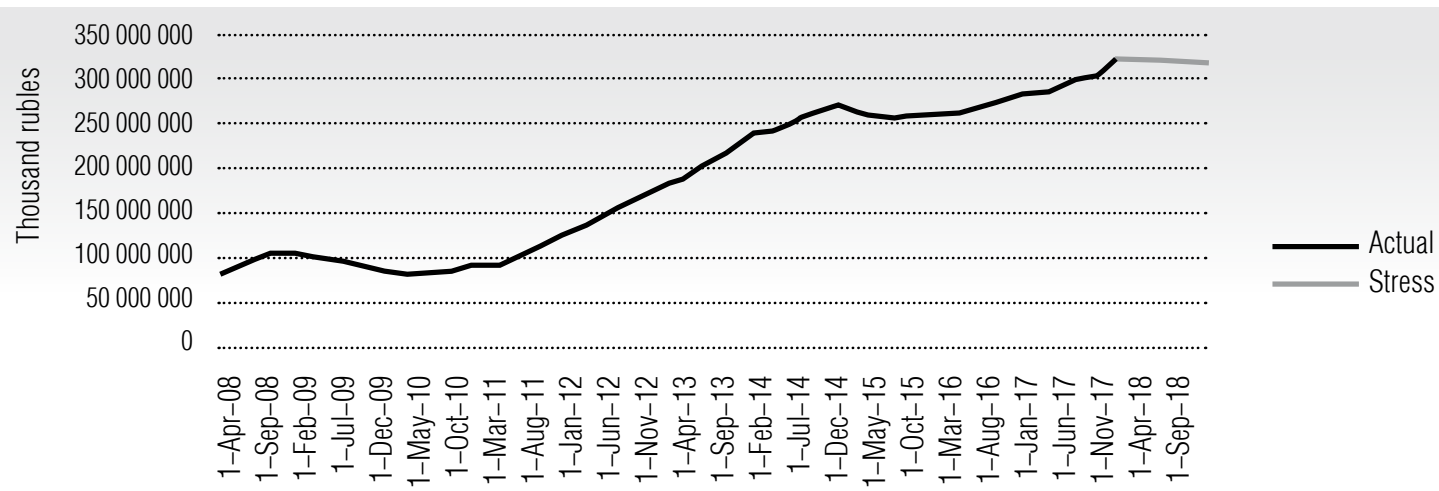

Fig. 4. The actual and forecasted values of retail loans portfolio

Table 7.

Results of modeling the corporate loans portfolio

\begin{tabular}{c|c|c|c|c} 
Variable & Coefficient & Test & Statistics & $p$-value \\
constant & 27.13 & Darbin-Watson & 1.55 & \\
\hline $\operatorname{pcy}\left(y_{t-1}\right)$ & $0.87^{\star * \star}$ & Breusch-Godfrey & 1.65 & 0.2 \\
\hline$x_{1, t}$ & $-2.34^{\star}$ & Breusch-Pagan-Godfrey & 0.86 & 0.46 \\
\hline$x_{2, t-1}$ & $0.03^{*}$ & White test & 0.94 & 0.5 \\
\hline $\mathrm{R}^{2} \mathrm{adj}$ & 0.80 & \multicolumn{2}{|}{} \\
\hline MAPE & $7.61 \%$ & \multicolumn{3}{|l}{} \\
\hline
\end{tabular}

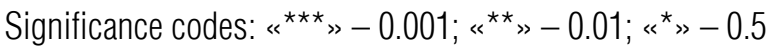




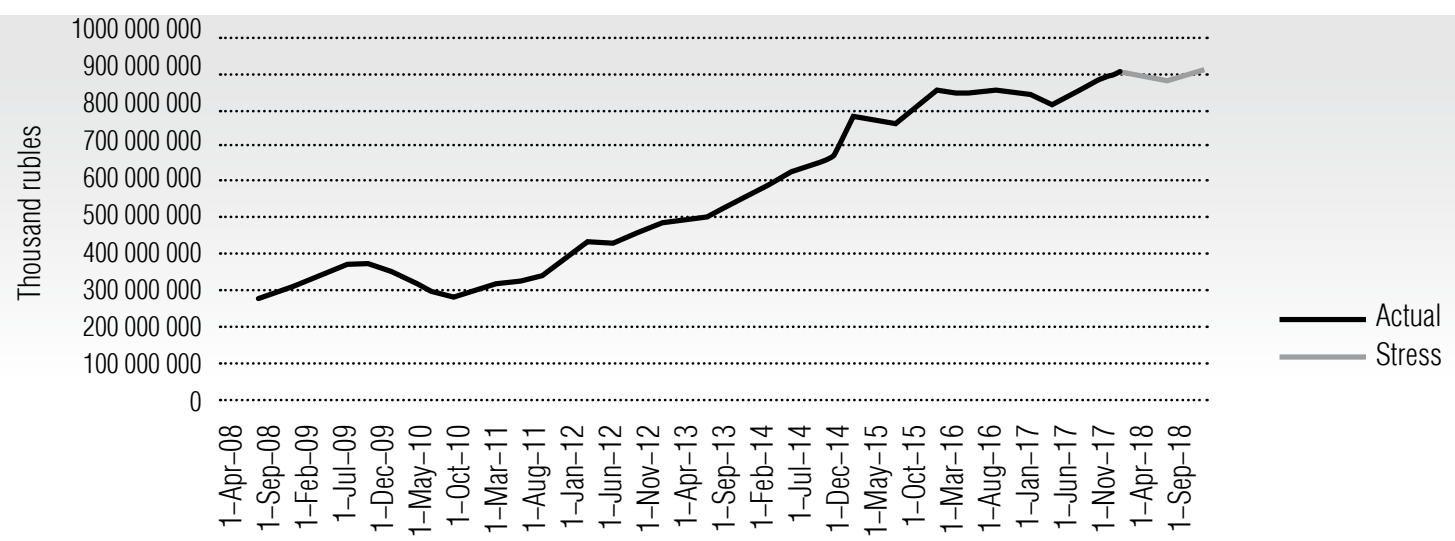

Fig. 5. The actual and forecasted values of corporate loans portfolio

$y_{t}$ - corporate LLP;

$x_{1, t}-$ real GDP growth rate at time $t$ (in $\%$, compared to the same quarter of previous year);

$x_{2, t}$ - the mean price of Brent oil at time $t$ (in US dollars).

The model is adequate and suitable for prediction. The adjusted $\mathrm{R}^{2}$ value is high, and the average modeling error is low. There is no autocorrelation and heteroscedasticity. The actual and forecasted values of corporate loans loss provisions of banks of the second cluster in the stress period are shown in Figure 7.

\section{Modeling the volume of funds on individuals' current accounts}

Interest rates on deposits of individuals negatively affect the amount of funds on the cur- rent accounts of individuals of banks of the second cluster. This is because with the growth of interest rates on deposits, people prefer to transfer money from current accounts to deposits. The results of the model are presented in Table 10.

The following designations are used in the table:

$y_{t}$ - funds of current individuals' accounts;

$x_{1, t}-$ real GDP growth rate at time $\mathrm{t}$ (in \%, compared to the same quarter of previous year).

The results of the Breusch-Godfrey, BrueshPagan-Godfrey and White tests show the absence of autocorrelation and heteroscedasticity. The model is adequate and suitable for prediction. The actual and forecasted values of funds on individual current accounts in banks included in the second cluster during the stress period are shown in Figure 8.

\section{Retail LLP modelling resutls}

Table 8 .

\begin{tabular}{c|c|c|c|c} 
Variable & Coefficient & Test & Statistics & $p$-value \\
constant & $0.81^{\star}$ & Darbin-Watson & 1.19 & \\
\hline $\mathrm{pcy}\left(y_{t-1}\right)$ & $0.74^{\star * *}$ & Breusch-Godfrey & 3.36 & 0.004 \\
\hline$x_{1, t}$ & $-0.15^{\star}$ & Breusch-Pagan-Godfrey & 0.92 & 0.40 \\
\hline $\mathrm{R}^{2}$ adj & 0.88 & White test & 1.3 & 0.28 \\
\hline $\mathrm{MAPE}$ & $8.56 \%$ & \multicolumn{3}{|}{} \\
\hline
\end{tabular}

Significance codes: « ${ }^{\star \star \star} »-0.001 ; «^{\star \star} »-0.01 ;\left\langle^{\star} »-0.5\right.$ 


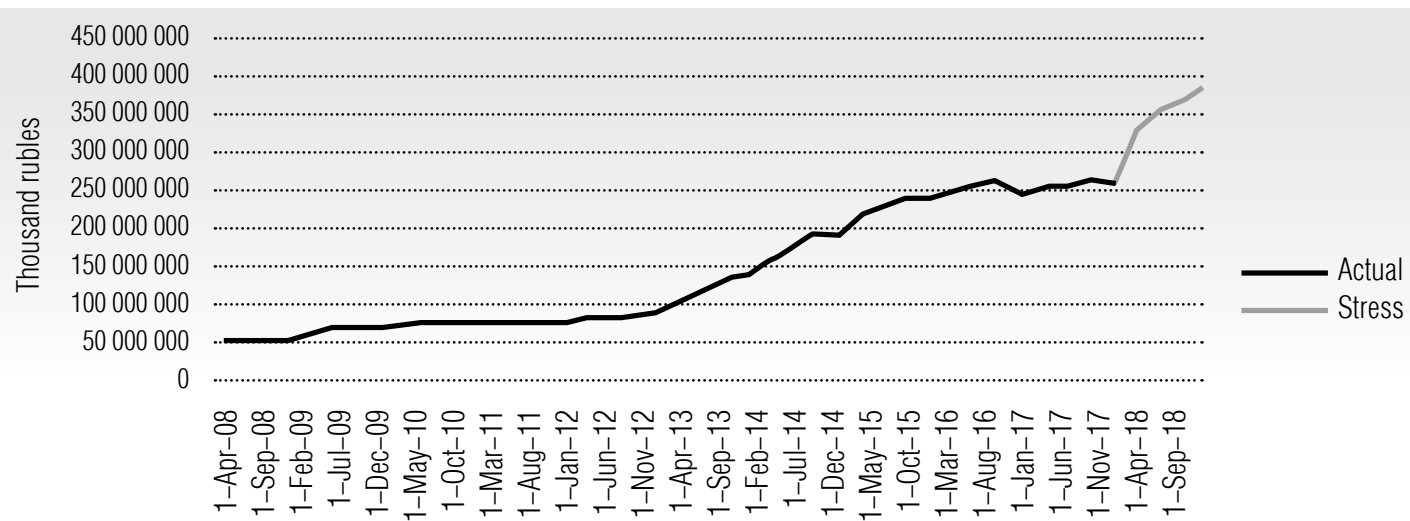

Fig. 6. The actual and forecasted values of the retail loans loss provision

Resutls of corporate LLP modeling

Table 9.

\begin{tabular}{c|c|c|c|c} 
Variable & Coefficient & Test & Statistics & p-value \\
constant & $-6.25^{\star}$ & Darbin-Watson & 2.10 & \\
\hline $\operatorname{pcy}\left(y_{t-1}\right)$ & $0.6^{\star \star *}$ & Breusch-Godfrey & 0.12 & 0.88 \\
\hline$x_{1, t}$ & $-6.4^{\star \star}$ & Breusch-Pagan-Godfrey & 0.91 & 0.44 \\
\hline$x_{2, t}$ & $-0.24^{\star \star}$ & White test & 0.63 & 0.57 \\
\hline $\mathrm{R}^{2}$ adj & 0.92 & \multicolumn{2}{|}{} \\
\hline MAPE & $6.43 \%$ & \multicolumn{3}{|l}{} \\
\hline
\end{tabular}

Significance codes: « ${ }^{\star \star \star} »-0.001 ; «^{\star \star} »-0.01 ; «^{\star} »-0.5$

\section{Modeling the volume of funds on corporate settlement accounts}

The annual growth rate of investments in fixed assets is a factor determining the amount of funds in the corporate settlement accounts of banks of the second cluster. The results of the model are presented in Table 11.

The following designations are used in the table:

$y_{t}-$ the volume of funds on corporate settlement accounts;

$x_{1, t}$ - the growth rate of investment in fixed assets at time $t$ (in \%, compared to the same quarter of previous year).

The adequacy of the model is confirmed by tests for the presence of autocorrelation and heteroscedasticity, indicating their absence. A small MAPE and a high value of corrected $\mathrm{R}^{2}$ indicate the suitability of the model for prediction. The actual and forecasted volumes of funds in the settlement accounts of legal entities of banks of the second cluster in the stress scenario are shown in Figure 9.

The forecast values of quarterly growth rates of the analyzed bank indicators of the cluster are given in Table 12 and in Figure 10.

It should be noted that the volume of loan portfolios have a certain tendency to decrease, while growth of corporate and individuals deposits in the stressful period is predicted. This growth can be explained by the fact that banks, mainly state-owned and systemically significant credit organizations, fall into the second cluster. This means that during crisis periods the probability of default of these banks is extremely low, which is a determining factor for depositors when choosing a bank. 


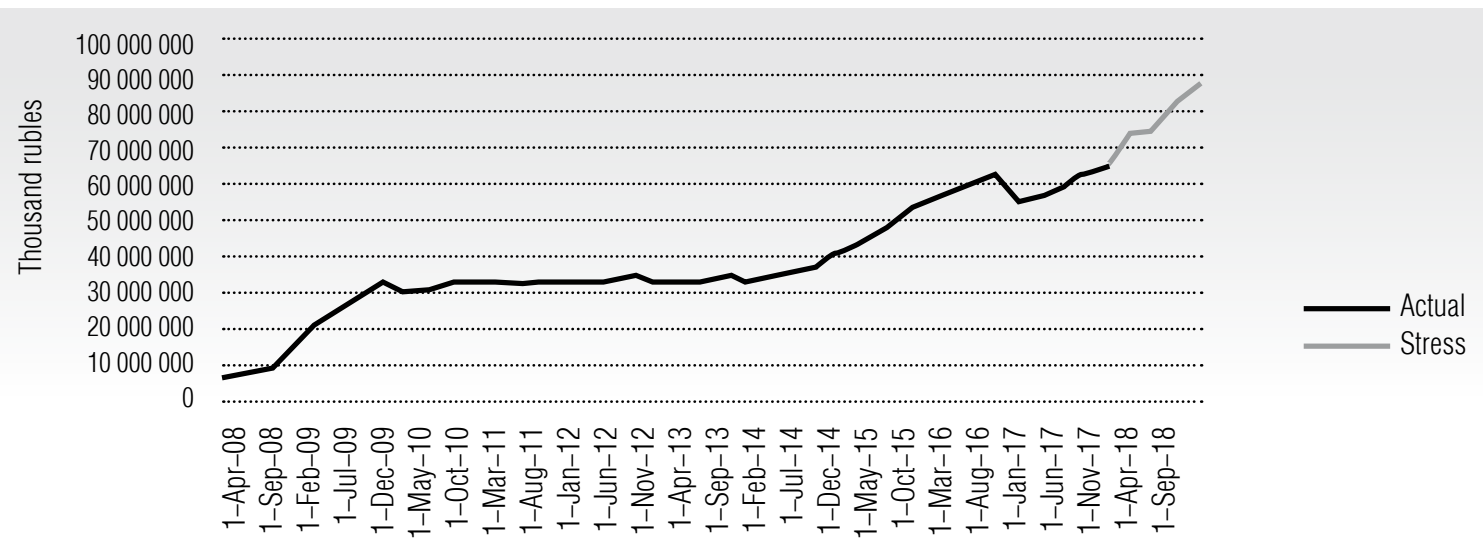

Fig. 7. The actual and forecasted values corporate LLP

Results of modeling funds on individuals' current accounts

Table 10.

\begin{tabular}{c|c|c|c|c} 
Variable & Coefficient & Test & Statistics & p-value \\
constant & $34.07^{\star *}$ & Darbin-Watson & 2.13 & \\
\hline $\mathrm{pcy}\left(y_{t-1}\right)$ & $0.54^{\star \star *}$ & Breusch-Godfrey & 0.36 & 0.68 \\
\hline$x_{1, t}$ & $-2.93^{\star \star}$ & Breusch-Pagan-Godfrey & 0.37 & 0.69 \\
\hline $\mathrm{R}^{2}$ adj & 0.68 & White test & 0.45 & 0.8 \\
\hline MAPE & $9.24 \%$ & \multicolumn{2}{|l}{} \\
\hline
\end{tabular}

Significance codes: « ${ }^{\star \star \star} »-0.001 ; «^{\star \star} »-0.01 ;\left\langle^{\star} »-0.5\right.$

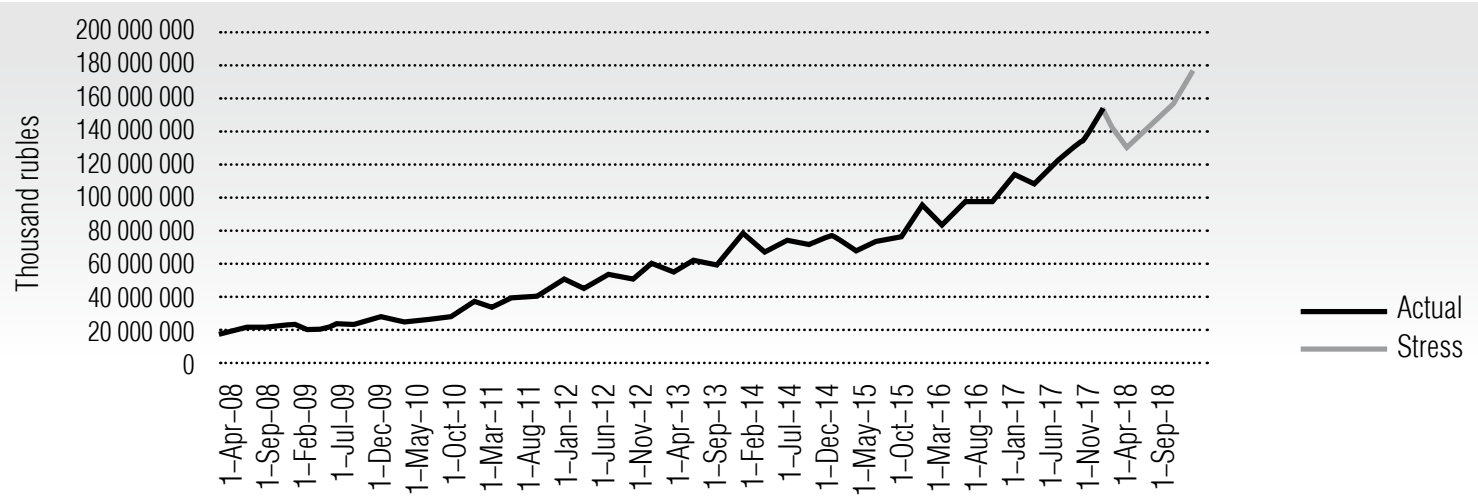

Fig. 8. The actual and forecasted values of funds on individuals' current accounts

\subsection{Stress test results}

Of the 26 banks of the second cluster, nine are systemically important credit organizations. According to the results of the stress testing of the banks of the second cluster, 11 banks (of which three are systemically significant), were observed to violate capital adequacy requirements. Table 13 shows the values of capital ade- quacy prior to the start of stress testing (as of 01 January 2018 - "before stress") and according to the results of modeling a stressful situation (as of 01 January 2019 - "after stress").

Figure 10 shows graphs of average values of the capital adequacy $\mathrm{H}_{1.0}(\%)$, basic capital $\mathrm{H}_{1.1}$, (\%) and fixed capital $\mathrm{H}_{1.2}(\%)$ before the start of stress testing (as of 01 January 2018 - "before 


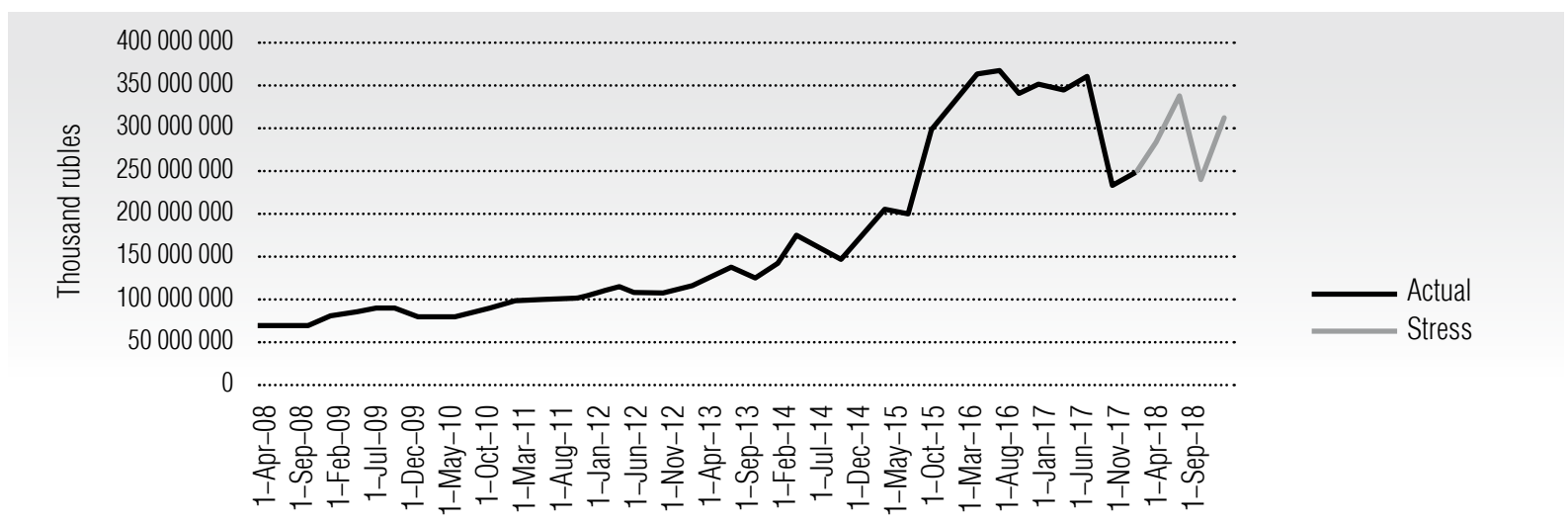

Fig. 9. The actual and forecasted values of funds on corporate settlement accounts

Results of modeling funds on corporate settlement accounts

Table 11.

\begin{tabular}{c|c|c|c|c} 
Variable & Coefficient & Test & Statistics & $\boldsymbol{p}$-value \\
constant & $4.93^{*}$ & Darbin-Watson & 1.77 & \\
\hline $\operatorname{pcy}\left(y_{t-1}\right)$ & $0.71^{* * *}$ & Breusch-Godfrey & 0.71 & 0.49 \\
\hline$x_{1, t}$ & $-0.71^{*}$ & Breusch-Pagan-Godfrey & 1.45 & 0.24 \\
\hline $\mathrm{R}^{2}$ adj & 0.58 & White test & 0.57 & 0.71 \\
\hline $\mathrm{MAPE}$ & $13.44 \%$ & \multicolumn{3}{|l}{} \\
\hline
\end{tabular}

Significance codes: « ${ }^{\star \star \star} »-0.001 ; «^{\star \star \star} »-0.01 ; «^{\star} »-0.5$

\section{Predicted values of quarterly growth rates of banking indicators of the second cluster in a stress scenario}

\begin{tabular}{c|c|c|c|c|c|c|c|c}
$\begin{array}{c}\text { Quarter } \\
\text { of } 2018\end{array}$ & $\begin{array}{c}\text { Retail } \\
\text { loans }\end{array}$ & $\begin{array}{c}\text { Corporate } \\
\text { loans }\end{array}$ & $\begin{array}{c}\text { Individuals' } \\
\text { deposits }\end{array}$ & $\begin{array}{c}\text { Corporate } \\
\text { deposits }\end{array}$ & $\begin{array}{c}\text { Retail } \\
\text { LLP }\end{array}$ & $\begin{array}{c}\text { Corporate } \\
\text { LLP }\end{array}$ & $\begin{array}{c}\text { Individuals' } \\
\text { funds }\end{array}$ & $\begin{array}{c}\text { Corporate } \\
\text { funds }\end{array}$ \\
\hline 1 & -0.16 & -0.89 & 3.26 & 3.80 & 24.05 & 13.73 & -16.12 & 15.27 \\
\hline 2 & -0.26 & -1.17 & 2.85 & 2.43 & 8.48 & 1.22 & 8.16 & 19.33 \\
\hline 3 & 0.71 & 0.71 & 2.52 & 1.09 & 4.21 & 10.13 & 9.60 & -29.40 \\
\hline 4 & -1.03 & 0.39 & 2.68 & 0.03 & 4.32 & 6.77 & 15.63 & 30.98 \\
\hline
\end{tabular}

stress") and based on the results of stress modeling (as of 01 January 2019 - "after stress"), since the forecasting horizon is 4 quarters), for banks forming the second cluster.

As can be seen from Figure 10, the adequacy of all types of capital for banks of the second clus-

Table 12.

ter, on the basis of stress testing of credit risk, decreased on average by about $2 \%$. Thus, the adequacy of total capital decreased from $13.37 \%$ to $11.32 \%$, the adequacy of basic capital from $9.93 \%$ to $7.78 \%$, and the capital adequacy ratio from $10.19 \%$ to $8.05 \%$. 
The results of stress testing of credit risk of banks of the second cluster

\begin{tabular}{|c|c|c|c|c|c|c|c|c|c|}
\hline \multirow{2}{*}{$\begin{array}{l}\text { License } \\
\text { Number }\end{array}$} & \multirow{2}{*}{ Bank } & \multicolumn{2}{|c|}{$\mathrm{H} 1.0(\%)$} & \multicolumn{2}{|c|}{$\mathrm{H} 1.1(\%)$} & \multicolumn{2}{|c|}{ H1.2 (\%) } & \multirow{2}{*}{$\begin{array}{l}\text { Require- } \\
\text { ments } \\
\text { violation }\end{array}$} & \multirow{2}{*}{$\begin{array}{c}\text { Capital } \\
\text { deficit } \\
\text { (thousands } \\
\text { of rubles) }\end{array}$} \\
\hline & & $\begin{array}{l}\text { Before } \\
\text { stress }\end{array}$ & $\begin{array}{l}\text { After } \\
\text { stress }\end{array}$ & $\begin{array}{l}\text { Before } \\
\text { stress }\end{array}$ & $\begin{array}{c}\text { After } \\
\text { stress }\end{array}$ & $\begin{array}{l}\text { Before } \\
\text { stress }\end{array}$ & $\begin{array}{l}\text { After } \\
\text { stress }\end{array}$ & & \\
\hline 1000 & VTB Group & 11.28 & 10.59 & 8.87 & 8.19 & 9.09 & 8.39 & 1 & 3927623 \\
\hline 1326 & Alfa Bank & 12.04 & 9.90 & 7.88 & 5.62 & 9.14 & 6.91 & 0 & 0 \\
\hline 1343 & Bank Levoberezhny & 14.97 & 12.67 & 9.66 & 7.15 & 9.66 & 7.15 & 0 & 0 \\
\hline 1439 & Vozrozhdenie Bank & 13.53 & 10.41 & 9.42 & 6.10 & 9.42 & 6.10 & 0 & 0 \\
\hline 1481 & Sberbank & 14.97 & 13.72 & 10.72 & 9.40 & 10.72 & 9.40 & 0 & 0 \\
\hline 1637 & SDM-Bank & 14.81 & 14.12 & 11.89 & 11.17 & 11.89 & 11.17 & 1 & 5711336 \\
\hline 1792 & Rusfinance Bank & 13.41 & 10.71 & 13.31 & 10.60 & 13.31 & 10.60 & 1 & 4953081 \\
\hline 1942 & Globexbank & 14.11 & 10.99 & 13.27 & 10.11 & 13.27 & 10.11 & 1 & 12979623 \\
\hline 2210 & TKB Bank & 11.08 & 8.39 & 7.70 & 4.88 & 7.70 & 4.88 & 1 & 3130759 \\
\hline 2272 & Rosbank & 13.10 & 11.93 & 9.22 & 7.96 & 9.22 & 7.96 & 0 & 0 \\
\hline 2289 & Russian Standard Bank & 12.50 & 7.78 & 9.54 & 4.53 & 9.54 & 4.53 & 1 & 98297 \\
\hline 2306 & Absolute Bank & 12.36 & 10.70 & 8.35 & 6.60 & 8.35 & 6.60 & 0 & 0 \\
\hline 2312 & Bank DOM.RF & 10.55 & 8.30 & 7.68 & 5.33 & 7.68 & 5.33 & 0 & 0 \\
\hline 2440 & Metallinvestbank & 12.75 & 11.59 & 8.98 & 7.75 & 8.98 & 7.75 & 0 & 0 \\
\hline 2590 & Ak Bars Bank & 14.72 & 13.40 & 10.53 & 9.14 & 10.53 & 9.14 & 1 & 1768125 \\
\hline 2707 & Loko Bank & 13.89 & 12.63 & 12.01 & 10.71 & 12.01 & 10.71 & 0 & 0 \\
\hline 316 & Home Credit Bank & 13.92 & 12.54 & 9.92 & 8.46 & 9.92 & 8.46 & 0 & 0 \\
\hline 328 & AB Rossia & 12.01 & 11.23 & 7.77 & 6.95 & 8.43 & 7.61 & 0 & 0 \\
\hline 3292 & Raiffeisen Bank & 13.27 & 12.14 & 9.94 & 8.75 & 10.63 & 9.45 & 1 & 42362841 \\
\hline 3311 & Credit Europe Bank & 14.41 & 10.45 & 11.80 & 7.65 & 11.80 & 7.65 & 1 & 1586504 \\
\hline 3349 & Russian Agricultural Bank & 15.55 & 13.99 & 10.41 & 8.74 & 10.94 & 9.28 & 0 & 0 \\
\hline 354 & Gazprombank & 12.75 & 11.48 & 8.70 & 7.39 & 9.07 & 7.75 & 1 & 1330903 \\
\hline 436 & Saint-Petersburg Bank & 14.27 & 11.91 & 10.05 & 7.55 & 10.05 & 7.55 & 0 & 0 \\
\hline 588 & SNGB Bank & 15.58 & 12.09 & 11.91 & 8.19 & 11.91 & 8.19 & 1 & 3927623 \\
\hline 705 & SKB Bank & 12.79 & 9.61 & 8.72 & 5.21 & 10.71 & 7.32 & 0 & 0 \\
\hline 963 & Sovkombank & 12.94 & 11.15 & 10.03 & 8.16 & 11.02 & 9.18 & 0 & 0 \\
\hline
\end{tabular}




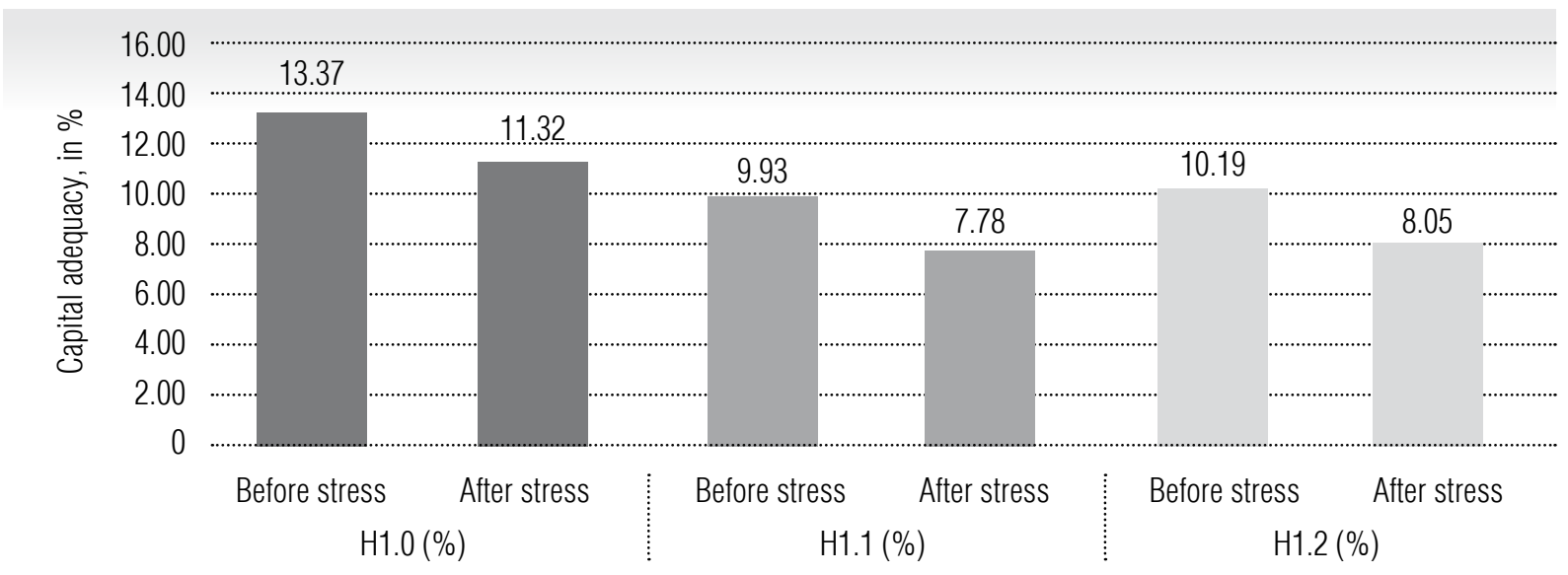

Fig. 10. The average values of the capital adequacy of all types of capital before the start of stress testing (as of 01 January 2018 - "before stress") and based on the results of stress modeling (as of 01 January 2019 - "after stress")

\section{Conclusion}

The proposed algorithm allows all counterparties of banks that have access only to public financial reports to conduct credit risk stress testing of the banks' cluster of interest, which can be used to evaluate which banks are most reliable in crisis situations. Using the example of credit risk stress testing conducted for a cluster of 26 banks, eight econometric models of banking indicators were developed, representing the median values of banking indicators included in this cluster of banks. According to the results of stress testing, 11 out of 26 banks forecast a deficit of all types of capital.

\section{References}

1. Bidzhoyan D., Bogdanova T. (2018) Russian banks credit risk stress-testing based on the publicly available data. Advances in Intelligent Systems and Computing, vol. 850, pp. 262-271.

2. Arena M. (2008) Bank failures and bank fundamentals: A comparative analysis of Latin America and East Asia during the nineties using bank-level data. Journal of Banking and Finance, no 32, pp. 299-310.

3. Makinen M., Solanko L. (2018) Determinants of banks closure: Do levels or changes of CAMEL variables matter? Russian Journal of Money and Finance, vol. 77, no 2, pp. 3-21.

4. Mitchell T. (2015) Bank default prediction: A comparative model using principal component analysis. Journal of Stock and Forex Trading, vol. 4, no 2, pp. 677-689.

5. Karminsky A.M., Kostrov A.V. (2014) Modelling the likelihood of Russian bank's default: extended opportunities. Journal of the New Economic Association, vol. 17, no 1, pp. 64-86 (in Russian).

6. Peresetsky A.A. (2010) Models of Russian bank's license revocation reasons. Working paper WP/2010/085. Moscow: RES (in Russian).

7. Karmisky A., Khromova E. (2016) Modelling banks' credit rating of international agencies. Eurasian Economic Review, vol. 6, no 3, pp. 341-363.

8. Goldewski C.J. (2007) Are ratings consistent with default probabilities? Empirical evidence on banks in emerging market economies. Emerging Markets Finance and Trade, vol. 43, no 4, pp. 5-23.

9. Avrikan N., McCrystal A. (2012) Sensitivity analysis of network DEA: NSBM versus NRAM. Applied Mathematics and Computation, vol. 218, no 22, pp. 11226-11239.

10. Karas A., Schoors K., Weill L. (2010) Are private banks more efficient than public banks? Evidence from Russia. Economics of Transition, vol. 18, no 1, pp. 209-244.

11. Gonzales F. (2005) Bank regulation and risk-taking incentives: An international comparison of bank risk Journal of Banking and Finance, vol. 29, no 5, pp. 1153-1184. 
12. Ungan E., Caner S., Ozyildirim S. (2008) Depositors's assessment of bank riskiness in the Russian Federation. Journal of Financial Services Research, vol. 33, no 2, pp. 77-110.

13. Peresetsky A.A. (2012) Econometric methods in off-site analysis of Russian banks. Moscow: HSE (in Russian).

14. Blaschke W., Jones T., Magnoni G., Peria S.-M. (2001) Stress-testing of financial systems: An overview of issues, methodologies, and FSAP experience. IMF Working Paper WP/01/88.

15. Melecky M. Podperia A. (2010) Macro prudential stress-testing practices of central banks in central and eastern Europe: an overview and challenges ahead. World Bank Policy Research Working Paper WP/2010/09/01.

16. Foglia A. (2009) Stress testing credit risk: a survey of authorities approaches. International Journal of Central Banking, vol. 5, no 3, pp. 9-45.

17. Breuer T., Summer M. (2017) Solvency stress testing of banks: Current practice and novel options. Report for the Sveriges Riksbank and Finansinspektionen.

18. Breuer T. Csiszar I. (2013) Systematic stress test with entropic plausibility constraints. Journal of Banking and Finance, no 37, pp. 1552-1559.

19. Breuer T., Csiszar I. (2016) Measuring distribution model risk. Mathematical Finance, vol. 26, no 2, pp. 395-411.

20. Kapinos P., Mitnik O. (2016) A top-down approach to stress-testing of banks. Journal of Financial Services Research, vol. 49, no 2, pp. 229-264.

21. Pritsker M. (2017) Choosing stress scenarios for systemic risk through dimension reduction. Federal Reserve Bank of Boston Working Paper WP17-04.

22. Shleifer A. Vishny R. (1992) Liquidation values and debt capacity: a market equilibrium approach. Journal of Finance, vol. 47, no 4, pp. 1343-1366.

23. Cont R., Wagalath L. (2016) Fire sales forensics: Measuring endogenous risk. Mathematical Finance, vol. 26, no 4, pp. 835-866.

24. Pedersen L. (2009) When everyone runs for exit. International Journal of Central Banking, vol. 5, no 4, pp. 177-199.

25. Bidzhoyan D.S., Bogdanova T.K., Neklyudov D.Yu. (2018) Evaluating reliability of a bank as an investment object. St. Petersburg State Polytechnical University Journal. Economics, vol. 11, no 4, pp. 70-84 (in Russian).

\section{About the authors}

\section{Davit S. Bidzhoyan}

Lecturer, Department of Business Analytics, National Research University Higher School of Economics, 20, Myasnitskaya Street, Moscow 101000, Russia;

E-mail: bidzhoyan_david@mail.ru

ORCID: 0000-0002-3668-1691

\section{Tatiana K. Bogdanova}

Cand. Sci. (Econ.);

Associate Professor, Department of Business Analytics,

National Research University Higher School of Economics,

20, Myasnitskaya Street, Moscow 101000, Russia;

E-mail: tanbog@hse.ru

ORCID: 0000-0002-0018-2946

\section{Dmitry Yu. Neklyudov}

Senior Lecturer, Department of Business Analytics,

National Research University Higher School of Economics,

20, Myasnitskaya Street, Moscow 101000, Russia;

E-mail: nekludovmid@gmail.com

ORCID: 0000-0002-9165-280X 